\title{
POLITICAL CONNECTION : SEBUAH PERTIMBANGAN DALAM PENENTUAN TINGKAT BUNGA
}

\author{
Supriyatini $^{1}$, R. Nelly Nur Apandi ${ }^{2}$ \\ 1,2Program Studi Akuntansi, Fakultas Pendidikan Ekonomi dan Bisnis, \\ Universitas Pendidikan Indonesia, Bandung, Indonesia. \\ supriyaatini@gmail.com¹, nellynurapandi.upi@gmail.com²
}

\begin{abstract}
This study aims to determine the effect of tax aggressive on the cost of debt with political connections as a moderating variable in manufacturing sector companies from 2017 to 2018. The sampling method used was purposive sampling with a sample of 75 companies from 156 manufacturing companies. The data used are secondary data in the form of financial statements and annual reports. The level of the company's cost of debt is measured using the percentage of interest expense, tax aggressive is measured using the effective tax rate, and political connection is measured using a dummy variable. Hypothesis testing is done by using panel data regression analysis with the help of eviews 11 software. Hypothesis testing results show that tax aggressive has a positive effect on cost of debt and the relationship between tax aggressive and cost of debt can be strengthened with a political connection.
\end{abstract}

Keywords: tax aggressive, political connection, cost of debt

\begin{abstract}
Abstrak
Penelitian ini bertujuan untuk mengetahui pengaruh tax aggressive terhadap cost of debt dengan political connection sebagai variabel pemoderasi pada perusahaan sektor manufaktur periode 2017 hingga 2018. Metode pengambilan sampel yang digunakan adalah purposive sampling dengan sampel 75 perusahaan dari 156 perusahaan manufaktur. Data yang digunakan adalah data sekunder berupa laporan keuangan dan laporan tahunan. Tingkat cost of debt perusahaan diukur menggunakan persentase beban bunga, tax aggressive diukur menggunakan effective tax rate, dan political connection diukur menggunakan variabel dummy. Pengujian hipotesis dilakukan dengan menggunakan analisis regresi data panel dengan bantuan software Eviews 11 . Hasil pengujian hipotesis menunjukkan bahwa tax aggressive berpengaruh positif terhadap cost of debt dan hubungan antara tax aggressive dengan cost of debt dapat menguat dengan adanya political connection.
\end{abstract}

Kata Kunci: tax aggressive, political connection, cost of debt

Corresponding author: Email : supriyaatini@gmail.com

History of article : Received: Juli 2019, Revised : September 2019, Published November 2019 


\section{PENDAHULUAN}

Dalam dunia bisnis sekarang ini, globalisasi membuat persaingan antar perusahaan menjadi semakin ketat. Para pelaku bisnis baik dari perusahaan jasa, perusahaan dagang maupun perusahaan manufaktur cituntut untuk tetap unggul dalam persaingan guna mempertahankan kelangsungan usahanya. Salah satu cara untuk menghadapi persaingan adalah dengan melakukan ekspansi bisnis (Sjahrial, 2014, hlm. 250).

Dalam pelaksanaan ekspansi bisnis, perusahaan selalu dihadapkan pada masalah keterbatasan dana. Untuk memenuhi kebutuhan dana, perusahaan dapat memperoleh dana baik dari sumber dana internal maupun sumber dana eksternal (IAI, 2015, hlm. 84). Banyak perusahaan memilih pembiayaan eksternal sebagai sumber dana usahanya karena dana yang diperoleh lebih cepat daripada sumber dana internal. Menurut Kepala Riset OSO Sekuritas, Riska Afriani, banyak perusahaan masih memilih pinjaman perbankan karena pendanaan konvensional ini dinilai lebih praktis bagi perusahaan. Hal serupa dilontarkan analis Indosurya Sekuritas, Willian Surya Wijaya, yang mengatakan bahwa faktor penyebab pembiayaan kredit diminati adalah pembiayaan melalui perbankan dapat ditempuh dalam waktu yang singkat (Kontan, 2018).

Tabel 1

Jumlah Kredit Bank Umum di Indonesia (miliar rupiah)

\begin{tabular}{|c|c|c|c|}
\hline Bulan & 2015 & 2016 & 2017 \\
\hline Januari & 1.712 .819 & 1.839 .577 & 1.969 .299 \\
\hline Februari & 1.732 .861 & 1.824 .382 & 1.963 .139 \\
\hline Maret & 1.729 .294 & 1.848 .712 & 2.007 .858 \\
\hline April & 1.754 .591 & 1.847 .163 & 2.033 .359 \\
\hline Mei & 1.777 .563 & 1.891 .051 & 2.052 .719 \\
\hline Juni & 1.828 .211 & 1.961 .581 & 2.103 .048 \\
\hline Juli & 1.820 .058 & 1.930 .757 & 2.086 .898 \\
\hline Agustus & 1.846 .733 & 1.933 .052 & 2.083 .937 \\
\hline Sept & 1.891 .535 & 1.971 .580 & 2.130 .383 \\
\hline Oktober & 1.852 .716 & 1.966 .176 & 2.132 .175 \\
\hline Nov & 1.854 .210 & 1.990 .265 & 2.138 .876 \\
\hline Des & 1.916 .256 & 2.049 .098 & 2.222 .823 \\
\hline Sum : Otos Jasa Keuangan
\end{tabular}

Sumber : Otoritas Jasa Keuangan
Tabel 1 menunjukkan jumlah kredit yang dikeluarkan oleh bank umum untuk pembiayaan modal kerja. Hal ini menunjukkan perkembangan pinjaman kredit di Indonesia mengalami kenaikan yang ditandai dengan peningkatan jumlah kredit yang diberikan bank umum.Dalam melakukan penilaian risiko, kreditur dapat melihat performa perusahaan yang akan melakukan pinjaman. Sehingga semakin besar kreditur menilai risiko yang dimiliki perusahaan, semakin besar pula bunga yang dibebankan pada perusahaan tersebut (Santosa \& Kurniawan, 2016). Performa perusahaan dapat dilihat dari kemampuan perusahaan menghasilkan laba, kondisi arus kas perusahaan, serta perilaku perpajakannya seperti adanya indikasi perusahaan melakukan tindakan penghindaran pajak.

Di Indonesia, pajak menjadi sumber pendapatan utama negara. Dana yang dikeluarkan untuk membiayai pembangunan ditopang oleh pemasukan dari sektor pajak. Sehingga pajak merupakan bagian sangat penting dalam pembangunan nasional. Maka dari itu, penerimaan dalam negeri yang bersumber dari pajak terus ditingkatkan.

Tabel 2 Realisasi Penerimaan Pajak (triliun rupiah)

\begin{tabular}{|c|c|c|c|}
\hline Tahun & 2014 & 2015 & 2016 \\
\hline Target & $1.072,37$ & $1.294,26$ & $1.355,20$ \\
\hline Realisasi & 981,83 & $1.060,83$ & $1.105,81$ \\
\hline Capaian & $91,56 \%$ & $81,96 \%$ & $81,60 \%$ \\
\hline
\end{tabular}

Sumber: Direktorat Jenderal Pajak

Dalam Tabel 2, realisasi pajak setiap tahunnya terus mengalami penurunan. Hal ini tentu mengakibatkan negara kehilangan pendapatan yang harus diterima dari sektor utamanya. Maka dari itu, pemerintah mengupayakan peningkatan pendapatan negara melalui pajak yaitu dengan melakukan ekstentifikasi dan intensifikasi pajak (Supramono \& Damayanti, 2014). Bagi perusahaan, pajak merupakan beban yang harus ditanggung karena akan mengurangi laba bersih, sehingga 
perusahaan selalu berupaya agar pajak dibayar dalam jumlah yangpaling minimal (Chen dalam Astuti \& Aryani, 2016). perusahaan selalu berupaya agar pajak dibayar dalam jumlah yang seminimal mungkin (Chen dalam Astuti \& Aryani, 2016).

Dengan adanya kenaikan tarif pajak, memungkinkan perusahaan untuk melakukan tax agressive untuk menghindari pajak. Peningkatan perilaku agresivitas pajak ini akan membuat penilaian risiko yang dilakukan kreditur atas profil perusahaan menjadi lebih tinggi, sehingga mereka akan menetapkan bunga pinjaman yang tinggi pula. Akibatnya, perusahaan akan menanggung cost of debt yang juga tinggi. Koneksi politik merupakan bahasan yang cukup unik karena banyak perusahaan di Indonesia yang menempatkan orang yang memiliki kedekatan dengan pemerintah didalam struktur organisasi perusahaan, baik direktur maupun komisarisnya. Kedekatan para pelaku bisnis dengan pemerintah di Indonesia cukup tinggi, dimana para pebisnis sengaja membina koneksi politik untuk mengamankan dan memudahkan akses bisnis mereka termasuk dalam kepentingan perpajakan (Hidayati \& Diyanty, 2018).

Masri dan Martani (2012) dari hasil penelitiannya menunjukkan bahwa tindakan penghindaran pajak berpengaruh positif terhadap cost of debt. Penelitian ini juga pernah dilakukan oleh Santosa \& Kurniawan (2016) dan menunjukkan hasil yang konsisten dengan penelitian Masri \& Martani (2012). Namun, hasil yang berbeda ditunjukkan pada penelitian Zahro, dkk (2018), yang menyebutkan bahwa penghindaran pajak tidak mempengaruh i cost of debt. Dari sisi kreditur, perusahaan yang memiliki koneksi politik memberikan jaminan keyakinan akan kelangsungan hidup usahanya sehingga tingkat risiko yang dikenakan terhadap perusahaan tersebut menjadi kecil (Ming, 2018). Perusahaan yang terkoneksi politik dianggap masih cukup aman dan masih mampu mengendalikan usahanya, sehingga akan membuat bunga pinjaman yang dibebankan oleh kreditur pun rendah (Ming, 2018). Maka, pengaruh tax aggressive terhadap cost of debt akan meningkat jika perusahaan memiliki koneksi politik yang kuat karena penghindaran pajak yang dilakukan dianggap tidak terlalu berisiko.

Penelitian ini diharapkan dapat memberikan pemahaman mengenai pentingnya mengelola faktor yang mempengaruhi cost of debt agar tidak terlalu besar yang akan berdampak negatif untuk perusahaan. Selain itu, penelitian ini dapat digunakan sebagai bahan pertimbangan bagi pemerintah dalam pembuatan keputusan perubahan regulasi perpajakan di Indonesia atas adanya pengaruh koneksi politik terhadap perilaku tax aggressive. Berdasarkan pemaparan latar belakang peneliti tertarik untuk melakukan penelitian dengan judul "Political Connection: Sebuah Pertimbangan Dalam Penentuan Tingkat Bunga".

\section{KAJIAN PUSTAKA \\ Teori Modigliani-Miller Dengan Pajak}

Teori struktur modal pertama yaitu teori Modigliani-Miller atau yang biasa dikenal dengan sebutan teori MM. Teori ini dikeluarkan oleh Franco Modigliani dan Merton H. Miller pada tahun 1958. Teori MM dengan pajak menyatakan bahwa dengan adanya pajak pada perusahaan, faktor utang dapat menghemat perusahaan dalam membayar pajak karena pembayaran bunga yang timbul dari aktivitas berutang dapat menjadi pengurang atas penghasilan kena pajak sehingga terdapat penghematan pajak dan nilai perusahaan akan meningkat (Chandra, 2008). Teori ini mendorong perusahaan untuk memperbanyak utang karena semakin besar jumlah utang yang digunakan, maka nilai perusahaan akan semakin meningkat (Husnan \& Pudjiastuti, 2015, hlm. 279).

\section{Teori Signal (Signalling Theory)}

Sinyal adalah suatu tindakan yang diambil 
perusahaan untuk memberi petunjuk bagi investor tentang bagaimana manajemen memandang prospek perusahaan. Sinyal ini berupa informasi mengenai apa yang sudah dilakukan manajemen untuk merealisasikan keinginan pemilik. Informasi tersebut dapattersampaikan melalui pengaturan struktur modal perusahaan.. Signalling theory mengasumsikan bahwa manajemen selalu berkeinginan untuk memaksimalkan insentif yang diharapkan, sehingga membuatnya tidak menyampaikan informasi yang dimiliki secara penuh karena khawatir akan mempegaruhi nilai perusahaan (Santosa \& Kurniawan, 2016).

Perusahaan memberikan suatu informasi ke pasar yang dapat direspon sebagai suatu sinyal. Sinyal ini memberikan informasi kepada investor sehingga mereka mengetahui keadaan perusahaan dan prospek dimasa mendatang (Saputro, 2018). Setelah menerima informasi tersebut, investor akan menganalisisnya sebagai good news atau bad news dan hasilnya akan menjadi dasar pengambilan keputusan (Santosa \& Kurniawan, 2016).

\section{Kerangka Pemikiran dan Hipotesis Pengaruh Tax Aggressive Terhadap Cost of Debt}

Kreditur akan menerima return berupa bunga atas utang yang diberikan, return tersebut merupakan cost of debt bagi perusahaan. Cost of debt yang ditanggung perusahaan ditetapkan olehkreditur tergantung bagaimana pengelolaan manajemen terhadap perusahaan. Semakin besar kreditor menilai risiko perusahaan, tingkat bunga yang akan dibebankan pun semakin tinggi (Santosa \& Kurniawan, 2016). Perusahaan selalu mengupayakan tingkat laba yang tinggi. Namun, laba yang tinggi membuat pajak yang dibayar perusahaan menjadi tinggi pula. Salah satu upaya perusahaan dalam mengurangi jumlah beban pajak adalah dengan melakukan tax aggressive.

Perusahaan yang melakukan perencanaan pajak yang agresif akan mengurangi transparansi pelaporan keuangan (Ming, 2018). Hal ini terjadi karena kreditur akan memandang perilaku tax aggressive merupakan tindakan yang mengandung risiko sehingga kreditur akan meminta return yang tinggi (Masri \& Martani, 2012).

H1 : Tax Aggressive Berpengaruh Positif terhadap Cost of Debt.

\section{Pengaruh Political Connection Terhadap Cost of Debt}

Perusahaan yang memiliki koneksi politik akan menggunakan pengaruhnya untuk mendapatkan akses yang lebih mudah dalam memperoleh pinjaman (Harjan, Teng, Shah, \& Mohammed, 2019). Perusahaan yang terkoneksi politik lebih sering diawasi oleh pihak luar perusahaan. Hal ini mendorong manajemen perusahaan untuk terus memperbaiki kinerjanya. Meningkatnya kinerja perusahaan membuat risiko perusahaan juga kecil sehingga return yang diminta kreditur menjadi lebih rendah (Juniarti \& Sentosa, 2009). Semakin banyak orang politik dalam perusahaan, pengawasan terhadap kinerja perusahaan pun semakin efektif. Hal ini akan membuat kreditur menilai risiko perusahaan rendah sehingga akan menurunkan cost ofdebt yang harus ditanggung perusahaan (Juniarti \& Sentosa, 2009).

$\mathrm{H} 2$ : Political Connection Berpengaruh Negatif Terhadap Cost of Debt.

\section{Pengaruh Political Connection Memoderasi Hubungan Tax Aggressive Terhadap Cost ofDebt}

Dari sisi perusahaan, pajak merupakan beban yang harus ditanggung dan akan mengurangi laba. Perusahaan seringkali melakukan berbagai cara untuk dapat mengurangi pajak terutang. Maka, perusahaan membutuhkan perencanaan pajak yang tepat, salah satunya dengan melakukan agresivitas pajak (tax aggresive) (Suyanto \& Supramono, 2012). Koneksi politik memiliki dampak positif terhadap perusahaan. Dampak positif adanya koneksi politik disebut juga political 
favoritism effect adalah mendapat perlakuan istimewa dalam hal perpajakan dari pemerintah seperti dapat menghindari audit pajak, pengajuan pengurangan denda pajak, serta tindakan lain yang termasuk dalam tax evasion atau tax aggressive (Wicaksono, 2017). Perusahaan dengan koneksi politik mampu melakukan tax planning yang lebih agresif karena mendapat perlindungan dari pemerintah (Butje \& Tjondro, 2014). Menurut Kim \& Zang (dalam Ming, 2018), mengungkapkan pejabat pemerintah enggan menuntut perusahaan yang terkoneksi politik atas perencanaan pajak yang agresif karena masalah karir. Maka, semakin tinggi koneksi politik yang dimiliki suatu perusahaan, kecenderungan melakukan tindakan penghindaran pajak pun semakin besar.

H3 : Political Connection Memperkuat Hubungan Tax Aggressive Terhadap Cost of Debt.

\section{METODE PENELITIAN}

Penelitian ini menggunakan pendekatan kuantitatif dengan metode deskriptif dan verifikatif. Melalui penelitian deskriptif diperoleh gambaran mengenai tax aggressive dan political connection serta cost of debt. Sedangkan melalui penelitian verifikatif dapat diketahui pengaruh dari tax aggressive terhadap cost of debt yang dimoderasi oleh political connection pada perusahaan sektor manufaktur yang terdaftar di BEI tahun 2017 dan 2018.

\section{Definisi Operasional Variabel Tax Aggressive (X)}

Dalam penelitian ini variabel tax aggressive akan diukur menggunakan Effective Tax Rate (ETR). ETR merupakan rasio yang mengukur seberapa besar penghindaran pajak yang dilakukan perusahaan. ETR memiliki hubungan negatif dengan tax aggressive, sehingga semakin rendah ETR maka semakin tinggi perilaku tax aggressive, begitupun sebaliknya.

\section{Cost of Debt (Y)}

Dalam penelitian ini variabel cost of debt akan diukur dengan cara mengalikan tingkat bunga perusahaan dengan tarif setelah dikurangi pajak. Tingkat bunga perusahaan dapat diperoleh dari beban bunga dibagi jumlah pinjaman perusahaan dikali seratus. Semakin tinggi nilai cost of debt maka semakin tinggi pula perusahaan menanggung biaya utang atas pinjaman yang dilakukan.

\section{Political Connection (Z)}

Political connection dapat diukur menggunakan dummy, dengan ketentuan jika perusahaan memiliki koneksi politik maka akan diberi skor dummy $=1$, dan 0 jika sebaliknya. Kriteria yang digunakan untuk mendefinisikan political connection mengacu pada penelitian yang dilakukan oleh Ferdiawan \& Firmansyah (2017), yaitu :

1. Jika ada satu atau lebih direktur atau komisaris yang juga merupakan anggota DPR, anggota kabinet eksekutif, pejabat dalam salah satu institusi pemerintah termasuk militer, atau anggota partai politik.

2. Jika ada satu atau lebih direktur atau komisaris yang juga merupakan mantan anggota DPR, mantan anggota kabinet eksekutif, mantan pejabat dalam salah satu institusi pemerintah termasuk militer, atau mantan anggota partai politik.

3. Jika ada satu atau lebih pemilik/pemegang saham diatas $10 \%$ merupakan anggota partai politik, memiliki hubungan dengan politisi top, atau pejabat/mantan pejabat pemerintah termasuk militer.

\section{Populasi dan Sampel Penelitian}

Objek dalam penelitian ini menggunakan populasi perusahaan sektor manufaktur yang terdaftar di Bursa Efek Indonesia (BEI) tahun 2017 dan 2018. Sampai dengan akhir 2018, tercatat sebanyak 70 perusahaan sektor industri 
dasar dan kima, 43 perusahan sektor aneka industri, dan 43 perusahaan sektor industri barang konsumsi yang terdaftar di BEI. Maka, populasi dari penelitian ini berjumlah 156 perusahaan.

Teknik pengambilan sampel yang digunakan dalam penelitian ini adalah nonprobability sampling yaitu judgment sampling yang merupakan cara pengambilan sampel yang dilakukan berdasarkan kriteria atau pertimbanganpertimbangan, yang pada umumnya disesuaikan dengan tujuan atau masalah penelitian. Kriteria yang ditentukan untuk pengambilan sampel yaitu sebagai berikut:

1. Perusahaan sektor manufaktur yang terdaftar pada Bursa Efek periode 2017-2018

2. Perusahaan yang mempublikasikan laporan keuangan pada periode 2017 2018 secara terus menerus.

3. Perusahaan yang memperoleh laba, memiliki beban bunga, dan beban pajak.

Populasi pada penelitian ini disesuaikan atau diseleksi berdasarkan kriteriakriteria diatas, sehingga didapatkan sampel untuk penelitian ini berjumlah 73 perusahaan untuk setiap tahunnya.

\section{Model Penelitian}

Model penelitian untuk menguji hipotesis menggunakan model regresi dengan menambahkan political connection sebagai variabel pemoderasi dan variabel kontrol berupa umur perusahaan, ukuran perusahaan, serta pertumbuhan perusahaan. Penyajian atas model penelitian adalah sebagai berikut:

$\mathrm{COD}=\alpha+\beta_{1} \mathrm{ETR}+\beta_{2} \mathrm{PC}+\beta_{3} \mathrm{ETR} * \mathrm{PC}+$ $\beta_{4}$ Age $+\beta_{5}$ Size $+\beta_{6}$ Growth $+\varepsilon_{\text {it }}$

Keterangan:

$\alpha=$ Konstanta

$\beta=$ Koefisien Regresi

$\mathrm{COD}=$ Cost Of Debt

$\mathrm{ETR}=$ Effective Tax Rate

$\mathrm{PC}=$ Political Connection
Age $=$ Umur Perusahaan

Size $=$ Ukuran Perusahaan

Growth $=$ Pertumbuhan Perusahaan

\section{Teknik Analisis Data}

Teknik pengumpulan data yang digunakan dalam penelitian ini adalah dokumentasi. Sementara teknik analisis data yang digunakan yaitu analisis statistik dekriptif dan analisis regresi data panel dengan menggunakan bantuan perangkat lunak Microsoft Excel dan Eviews 11.

\section{HASIL DAN PEMBAHASAN Analisis Deskriptif}

\section{Tax Aggressive}

Berdasarkan periode pengamatan pada tahun 2017 dan 2018, hasil pengujian statistic menunjukkan bahwa variabel tax aggressive yang diproksikan oleh effective tax rate memiliki rata-rata sebesar 0,322 , dengan nilai tertinggi tertinggi sebesar 4,375 serta terendah $0,012, \mathrm{SD}=0,366$.

\section{Political Connection}

Hasilpengujian statistik, menunjukkan bahwa variabel political connection yang diukur menggunakan variabel dummy memiliki modus sebesar 0. Hal tersebut menandakan bahwa sebagian besar perusahaan manufaktur yang terdaftar di Bursa Efek Indonesia tahun 2017 dan 2018 tidak memiliki koneksi politik didalamnya.

\section{Cost of Debt}

Hasil pengujian statistik, bahwa variabel cost of debt memiliki rata-rata sebesar 0,193, dengan nilai tertinggi sebesar 1,340 dan nilai terendah sebesar 0,002 , serta memiliki standar deviasi sebesar 0,245.

\section{Pengujian Hipotesis}

\section{Hasil Uji Regresi Data Panel}

Hasil uji regresi data panel menunjukkan bahwa random effect model menjadi model yang paling sesuai diantara model yang lainnya.

\section{Pengaruh Tax Aggressive Terhadap Cost of Debt}


Salah satu tujuan dalam penelitian ini adalah untuk mengetahui apakah terdapat pengaruh tax aggressive terhadap cost of debt dengan studi pada perusahaan manufaktur tahun 2017-2018. Adapun dalam penelitian ini, tax aggressive diproksikan menggunakan Effective Tax Rate (ETR) pada masing-masing perusahaan. ETR memiliki hubungan terbalik dengan tax aggressive sehingga semakin tinggi nilai ETR maka semakin rendah tax aggressive yang dilakukan suatu perusahaan, namun semakin rendah nilai ETR maka perilaku tax aggressive suatu perusahaan semakin tinggi (Santosa \& Kurniawan, 2016). Pada hasil penelitian ini dapat disimpulkan bahwa perilaku tax aggressive menurun. Hal tersebut terbukti dari perubahan effective tax rate rata - rata pertahunyang meningkat dari tahun 2017 hingga sekitar 18,04\%. Setelah melakukan pengujian terhadap 146 sampel penelitian, didapatkan bahwa tax aggressive berpengaruh positif terhadap cost of debt. Hal tersebut terlihat dari hasil probabilitas effective tax rate sebesar $0,0713<0,10$ dengan koefisien negatif sebesar 0,169758 yang berarti semakin kecil effective tax rate, perilaku tax aggressive suatu perusahaan semakin besar maka biaya utang perusahaan pun semakin tinggi.

Maka dapat disimpulkan bahwa tax aggressive berpengaruh positif terhadap cost of debt. Hasil penelitian ini konsisten dengan hasil penelitian Masri \& Martani (2012) dan Santosa \& Kurniawan (2016) yang menyatakan bahwa tax aggressive berpengaruh positif terhadap cost of debt. Hal ini menunjukkan bahwa jika manajemen perusahaan ingin mengecilkan pembayaran pajak, maka semakin besar perusahaan memperoleh peinjaman untuk meningkatkan biaya utang. Selain itu, dalam Undang- Undang No. 28 Tahun 2007 tentang Ketentuan Umum dan Tata Cara Perpajakan disebutkan bahwa melakukan reformasi perpajakan dan meningkatkan pemberantasan korupsi, kreditur menilai perilaku tax aggressive sebagai tindakan yang mengandung risiko. Oleh karena itu, kreditur akan membebankan bunga yang lebih besar sehingga cost of debt yang ditanggung perusahaan juga semakin tinggi (Santosa \& Kurniawan, 2016).

\section{Pengaruh Political Connection Terhadap Cost Of Debt}

Pengujian selanjutnya akan dibahas mengenai pengaruh political connection terhadap cost of debt. Setelah melakukan pengujian terhadap 146 sampel penelitian, pengujian political connection terhadap cost of debt menunjukkan nilai probabilitas sebesar 0,4307, yang berarti political connection tidak berpengaruh signifikan terhadap besaran cost of debt. Penelitian Yoshinara (dalam Hardianti, 2015) menyatakan perusahaan terkoneksi politik sering disebut perusahaan risk taker karena sering menggunakan pengaruhnya untuk memperoleh pinjaman lunak yang lebih mudah. Pinjaman lunak ini digunakan untuk mengatasi krisis, sehingga perusahaan yang memiliki koneksi politik memiliki kemungkinan kegagalan yang lebih besar (Johnson \& Milton dalam Hardianti, 2015).

Oleh karena itu, kreditur akan memberikan tingkat bunga yang tinggi atas pinjaman yang dilakukan perusahaan. Sehingga, perusahaan yang memiliki koneksi politik akan mempunyai cost of debt yang tinggi pula. Sementara hasil penelitian Chaney et. al. pada tahun 2010 menemukan bahwa tingkat cost of debt cenderung lebih tinggi pada perusahaan yang tidak terkoneksi politik. Hal ini disebabkan perusahaan terkoneksi politik menghadapi lebih sedikit konsekuensi negatif akibat kualitas pengungkapan yang rendah (Tjondro \& Basuki, 2012). Perusahaan yang memiliki koneksi politik memperoleh keputusan kredit bank yang lebih menguntungkan dibanding perusahaan yang tidak memiliki hubungan politik yang disebut reputation of profitability (Tjondro \& Basuki, 2012).

Perbedaan penelitian diatas karena adanya perbedaan pandangan mengenai dampak koneksi politik terhadap risiko 
perusahaan. Hasil penelitian ini menunjukkan bahwa besarnya tingkat bunga lebih disebabkan oleh kondisi perusahaan itu sendiri yang menghasilkan suatu risiko sehingga mempengaruhi keputusan pemberian kredit terlepas didalamnya terdapat pelaku politik atau tidak. Dengan hasil penelitian tersebut dan beberapa teori pendukung maka penulis menyimpulkan bahwa political connection tidak berpengaruh terhadap cost of debt.

\section{Pengaruh Tax Aggressive Terhadap Cost of Debt Dengan Political Connection Sebagai Variabel Pemoderasi}

Pengujian selanjutnya akan dibahas mengenai pengaruh tax aggressive terhadap cost of debt dengan dimoderasi oleh variabel political connection. Setelah melakukan pengujian terhadap 146 sampel penelitian, didapatkan bahwa political connection memperkuat hubungan antara tax aggressive terhadap cost of debt. Hal tersebut terlihat dari hasil probabilitas sebesar $0,0874<0,10$ dengan koefisien positif sebesar 0,166579 yang berarti semakin besar tingkat political connection perusahaan maka semakin besar perilaku tax aggressive suatu perusahaan sehingga biaya utang perusahaan pun semakin tinggi.

Maka dapat disimpulkan bahwa political connection dapat menguatkan pengaruh tax aggressive terhadap cost of debt. Hasil penelitian ini sejalan dengan hasil penelitian Prasetyo (2017) yang menyatakan bahwa perusahaan yang terkoneksi politik cenderung melakukan tax aggressive. Pada umumnya perusahaan yang terkoneksi politik memiliki risiko peemriksaan pajak yang rendah karena politisi juga memberikan perlindungan pada perusahaan, sehingga perusahaan akan semakin agresif melakukan tax planning guna mengurangi pajak (Butje \& Tjondro, 2014).

Namun, hasil penelitian ini bertentangan dengan penelitian Zhang, et. al. (2012) yang menyatakan bahwa perusahaan yang memiliki koneksi politik mempunyai tingkat penghindaran pajak yang lebih rendah jika dibandingkan dengan perusahaan yang tidak memiliki koneksi politik. Hal ini dapat terjadi karena perusahaan yang terkoneksi politik lebih sering diawasi oleh pihak luar perusahaan sehingga mendorong manajemen perusahaan untuk terus memperbaiki kinerjanya. Meningkatnya kinerja perusahaan membuat risiko perusahaan menjadi kecil sehingga return yang diminta krediturpun lebih rendah (Juniarti \& Santosa, 2009).

\section{KESIMPULAN DAN SARAN}

Tax aggressive berpengaruh positif terhadap cost of debt. Artinya semakin tinggi penghindaran pajak yang dilakukan perusahaan maka akan semakin tinggi tingkat bunga yang diberikan kreditur atas pinjaman yang dilakukan.Political connection tidak berpengaruh terhadap cost of debt. Artinya ada atau tidaknya koneksi politik dalam suatu perusahaan, tidak akan mempengaruhi tingkat bunga yang diberikan kreditur. Political connection memperkuat hubungan tax aggressive dan cost of debt. Artinya, praktik penghindaran pajak yang dilakukan perusahaan akan semakun besar jika perusahaan memiliki koneksi politik didalamnya. Hal ini akan membuat kreditur menetapkan bunga yang tinggi pada perusahaan.

Berdasarkan hasil kesimpulan di atas, maka dapat diberikan saran.Diharapkan pihak manajemen perusahaan dapat lebih memperhatikan kinerja perusahaan agar dapat meningkatkan kepercayaan kreditur pada perusahaan tanpa harus mengandalkan manajemen laba ataupun koneksi politik dengan cara mempertahankan profesionalisme dalam menjalankan aktivitas operasional perusahaan sehingga tidak akan meningkatkan risiko perusahaan. Pihak manajemen diharapkan berperilaku dengan memperhatikan batasan-batasan yang ada, karena segala tindakan yang dilakukan perusahaan, baik dalam jangka pendek 
maupun Panjang, akan berdampak pada perusahaan itu sendiri. Untuk penelitian selanjutnya, penelitian ini diharapkan dapat menjadi acuan dalam penelitian yang berkaitan dengan faktor-faktor yang mempengaruhi cost of debt. Penelitian ini menggunakan sektor manufaktur saja dengan periode pengamatan yang relatif pendek selama dua tahun sehingga penelitian selanjutnya diharapkan dapat menambah sampel dari berbagai sektor perusahaan yang terdaftar di Bursa Efek Indonesia dan menambah periode pengamatan sehingga hasil penelitian dapat digeneralisir untuk semua sektor industri. Penelitian ini memiliki keterbatasan dimana koefisien determinasi masih relative rendah, karena masih ada variabel lain yang berpengaruh signifikan namun bukan variabel dalam penelitian ini sehingga penelitian selanjutnya dapat dikembangkan dengan menambahkan variabel lain yang mempengaruhi cost of debt. Selain itu, penelitian ini hanya menggunakan ETR sebagai indikator penghindaran pajak, padahal masih ada indikator lain yang dapat digunakan. Diharapkan penelitian selanjutnya dapat menggunakan indikator lain yang dapat digunakan seperti Cash ETR, Book Tax Difference, atau menggunakan laporan keuangan fiskal agar perhitungan tax aggressive perusahaan lebih akurat dan lebih mencerminkan keadaan yang sebenarnya.

\section{DAFTAR PUSTAKA}

Astuti, T. P., \& Aryani, Y. A. (2016). Tren Penghindaran Pajak Perusahaan Manufaktur Di Indonesia Yang Terdaftar Di BEI Tahun 2001-2014. Jurnal Akuntansi, $\quad$ 20(3),375388.

https://doi.org/10.24912/ja.v20i3.4

Batamnews. (2018). "4 Perusahaan Besar Mendadak Bangkrut, Ini Penyebabnya". [Online]. Diaksesdari https://www.batamnews.co.id/berita39529-4-perusahaan-besar-mendadakbangkrut-ini-penyebabnya.html [4Juli
2019]

Bursa Efek Indonesia. (2019). Laporan Keuangan dan Tahunan. [Online]. Diakses dari https://www.idx.co.id/perusahaantercatat/laporan-keuangan-dantahunan/ [4 Mei 2019]

Butje, S., \& Tjondro, E. (2014). Pengaruh Karakter Eksekutif dan Koneksi Politik Terhadap Tax Avoidance. Tax and Accounting Review, 4(2), 1-9.

Chandra, T. (2008). Perkembangan Teori Struktur Modal: Dari ModiglianiMiller, Myers, Sampai Jensen. Jurnal Teknologi Dan Manajemen Informatika, 6(4), 840-850.

Direktorat Jenderal Pajak. (2019). Laporan Kinerja. [Online]. Diakses dari https://www.pajak.go.id/id/kinerja-page [15 Juni 2019]

Ferdiawan, Y., \& Firmansyah, A. (2017). Pengaruh Political Connection, Foreign Activity, dan Real Earnings Management Terhadap Tax Avoidance. Jurnal Riset Akuntansi Dan Keuangan, 5(3), 1601-1624.

https://doi.org/10.17509/jrak.v5i3.9223 Harjan,

S. A., Teng, M., Shah, S. S. H., \&Mohammed, J. H. (2019). Political Connections and Cost of Debt Financing.

Empirical Evidence from China. International Journal of Economics and Financial Issues, 9(1), 212-216. https://doi.org/10.32479/ijefi.7561

Hidayati, W., \& Diyanty, V. (2018). Pengaruh Moderasi Koneksi Politik Terhadap Kepemilikan Keluarga dan Agresivitas Pajak. Jurnal Akuntansi Dan Auditing Indonesia, 22(1), 46-60.

Husnan, S., \& Pudjiastuti, E. (2015). DasarDasar Manajemen Keuangan. Yogyakarta: UPP STIM YKPN.

Juniarti, \& Sentosa, A. A. (2009). Pengaruh Good Corporate Governance, Voluntary Disclosure terhadap Biaya Hutang (Costs of Debt). Jurnal Akuntansi dan Keuangan, 11(2), 88100. 
Kompas. (2009). "Ditjen Pajak Selidiki Tunggakan Pajak Bakrie". [Online]. Diakses dari https://nasional.kompas.com/read/2 $\underline{009 / 1}$

2/16/13062669/ditjen.pajak.selidiki .tungg akan.pajak.bakrie [10 Juli 2019]

Maksudi, B. I. (2012). Sistem Politik Indonesia, Pemahaman Secara Teoritik dan Empirik. Jakarta: Rajawali Pers.

Mardiasmo. (2018). Perpajakan. Yogyakarta: ANDI.

Masri, I., \& Martani, D. (2012). Pengaruh Tax Avoidance Terhadap Cost of Debt. ttps://doi.org/10.1016/S0015282(16)59108-0

Meiriasari, V. (2017). Pengaruh Corporate Governance, Kepemilikan Keluarga, Kepemilikan Institusional dan Ukuran Perusahaan (Firm Size) Terhadap Biaya Utang. Jurnal Ekonomi Global Masa Kini, 8(1), 28-34.

Ming, T. C. (2018). Political Connections and The Cost of Debt: Reexamining The Evidence From Malaysia. Journal of Multinational Financial Management. https://doi.org/10.1016/j.mulfin.201 8.05 .003

Pernyataan Standar Akuntansi Keuangan Nomor 26 Revisi 2011 Tentang Biaya Pinjaman

Pranoto, B. A., \& Widagdo, A. K. (2015). Pengaruh Koneksi Politik dan Corporate GovernanceTerhadap Tax Aggressiveness.

Purwanti, S. M., \& Sugiyarti, L. (2017). Pengaruh Intensitas Aset Tetap, Pertumbuhan Penjualan dan Koneksi Politik Terhadap Tax Avoidance. Jurnal Riset Akuntansi Dan Keuangan, 5(3), 1625-1641 Putri, E. (2017).

Pengaruh Kualitas Auditor dan Komite Audit Terhadap Cost of Debt Dengan Usia Perusahaan Sebagai
Variabel Moderasi. U niversitas Lampung.

Putri, E. (2017). Pengaruh Kualitas Auditor dan Komite Audit Terhadap Cost of Debt dengan Usia Perusahaan Sebagai Variabel Moderasi. Universitas Lampung.

Putri, Nisa Dwiresya. (2018). "Ini alasan emiten lebih suka cara lama cari pendanaan". [Online]. Diakses dari https://investasi.ko ntan.co.id/news/ini- alasan-emitenlebih-suka-cara-lama- caripendanaan [7 Januari 2019]

Sahamok. (2017). Sektor Bursa Efek indonesia. [Online]. Diakses dari https://www.sahamok.com/emiten/sek t o r-bei/ [7 Januari 2019]

Santosa, J. E., \& Kurniawan,H. (2016). Analisis Pengaruh Tax Avoidance Terhadap Cost of Debt Pada Perusahaan Manufaktur YangTerdaftar di BEI SelamaPeriode 20102014.MODUS,28(2), 139-154.

Sartika, W. (2012). Analisis Hubungan Penghindaran Pajak Terhadap Biaya Hutang dan Kepemilikan Institusional Sebagai Variabel Pemoderasi. Universitas Indonesia.

Sherly, E. N., \& Fitria, D. (2016). Pengaruh Penghindaran Pajak, Kepemilikan Institusional, dan Profitabilitas Terhadap Biaya Hutang. Ekombis Review, 58-69.

Sjahrial, D. (2014). Manajemen Keuangan Lanjutan (Revisi). Jakarta: Mitra

Situmorang, Anggun P. (2018). "Sri Mulyani Beberkan Alasan Naikkan Tarif 1.147 Barang Impor". [Online]. Diakses dari https://www.liputan6.com/bisnis/re ad/ 363 7564/sri-mulyani-beberkanalasan- naikkan-tarif-1147-barangimpor?related=dable\&utm_expid=.
$9 \mathrm{Z}$ $4 \mathrm{i} 5$ ypGQeGiS7w9arwTvQ.1\&utm_ref err er= https\%3A\%2F\%2Fwww.google.co $\mathrm{m} \% 2 \mathrm{~F}$ [11 Januari 2019] 
Journal IMAGE | Volume 8, Number 2, November 2019, page 87-96 
Journal IMAGE | Volume 7, Number 2, November 2019, page 44-54 
Journal IMAGE | Volume 7, Number 2, November 2019, page 44-53 
Journal IMAGE | Volume 7, Number 2, November 2019, page 44-54 